\title{
Opportunity in the Time of COVID-I9. Learning Lessons to Improve Public Spaces
}

\author{
Miquel Martí, Lara Espindola \\ Universitat Politècnica de Catalunya, Spain \\ miquel.marti@upc.edu | laraespindola@gmail.com
}

\begin{abstract}
To face the COVIDI9 pandemic, cities have taken short term actions. Streets have been closed to traffic during weekends to enable temporary playgrounds or car lanes have been transformed into bike lanes or used to enlarge sidewalks following tactical urbanism practices. Time has appeared as a main factor in the management of public space (defining timeslots to exit to the street or trying to avoid peak hours in public transportation by extending the starting and ending working times). Technologies have been key, enabling online work, virtual gatherings and creative activities, as well as developing applications for better tracing the disease or enforcing the lockdown regulations. But what will be the lasting effects of these measures in the long-term transformations of cities?

This commentary was written in May 2020, in the middle of a total lockdown in Barcelona. It is based on the events, reflections and public opinion reactions at this precise moment in this particular place. It argues that the urban adaptations to the COVIDI9 could be an opportunity to adjust, strengthen and accelerate some ongoing urban strategies: the transition towards a more sustainable mobility and a greener city; the development of neighbourhood life; the application of technologies in urban planning and management, community-based initiatives and everyday public space experiences.
\end{abstract}

Keywords: COVID 19, urban mobility, neighbourhood, urban health, digital space

To cite this article:

Marti, M., Espindola, L. (2020). Opportunity in the Time of COVIDI9. Learning lessons to improve public spaces, The Journal of Public Space, 5(3), 23-30, DOI I0.3289I/jps.v5i3.I373

This article has been double blind peer reviewed and accepted for publication in The Journal of Public Space.

(i) This work is licensed under a Creative Commons Attribution - Non Commercial 4.0 International License https://creativecommons.org/licenses/by-nc/4.0/ 


\section{Introduction}

During these days of lockdown due to the COVIDI9 pandemic we have seen all around the world shocking images of empty public spaces. We can only conceive as temporary such pictures, and with the starting of scaling measures, streets are recovering immediately part of their life. Public space is the soul of most cities and a city without some kind of lively public spaces would be nonsense. Meanwhile, animals have occupied our streets, recalling us that either our cities recover a synergic relation with nature or the future of the planet could be a post human one (Weisman, 2007).

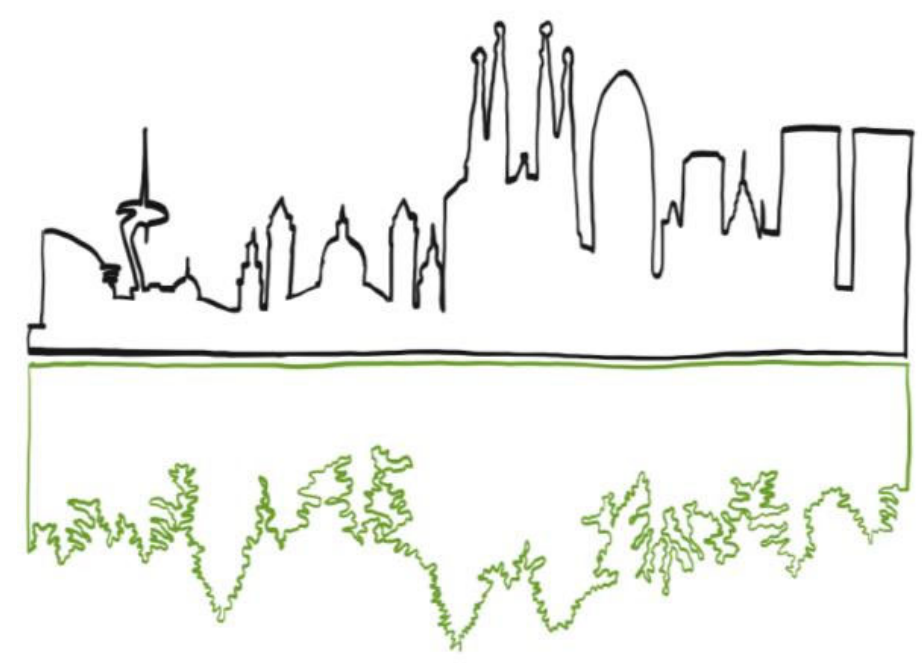

Figure I. City and nature: searching for synergies.

Source: by the authors, inspired in the cover image of the book The World without Us

The point is not if the post-COVID city will be a completely different one (which is not likely), but if in the mid-term (when a vaccine will be available) we will tend to live as we did before (which would be a pity). As many thinkers are stating these weeks (Noam Chomsky, Naomi Klein, Slavoj Zizek), the impact of the pandemic should be an opportunity to strengthen some changes that societies were already facing (Žižek, 2020).

From the particular perspective of public space, we think about three issues on which the COVIDI9 is having an impact that would be important to drive positively: the changes on the urban mobility and the redesign of the street network; the debate about density, complexity, proximity and the availability of open spaces under social distance conditions; the increasing role of information and communication technologies in planning, managing and experiencing cities.

\section{Impacts on urban mobility and the redesign of the street network}

Under the effects of the pandemic, the modes of transportation that we use to move around the city have changed. We have two opposite effects. On one hand, the capacity of public transit is diminishing because we can't travel so close ones to the others. One the other hand, online working has been spread and consolidated. Keeping some forms 
of online work once the lockdown will be finished could be a lasting effect of the crisis. This may be useful not only to reduce the number of commuters, but to make more flexible the working schedules (starting and ending times) in order to avoid the peak hours, when public transportation can be overwhelmed (Guerrero \& Muñoz, 2020). Public transit should be reinforced by upgrading the network of reserved lanes, increasing the frequencies and providing more public funding to compensate the reduction of incomes from users' tickets. Nevertheless, the weight of public transportation in the modal choice of citizens is expected to decrease. In those circumstances, are cities facing a rise in the use of private cars?
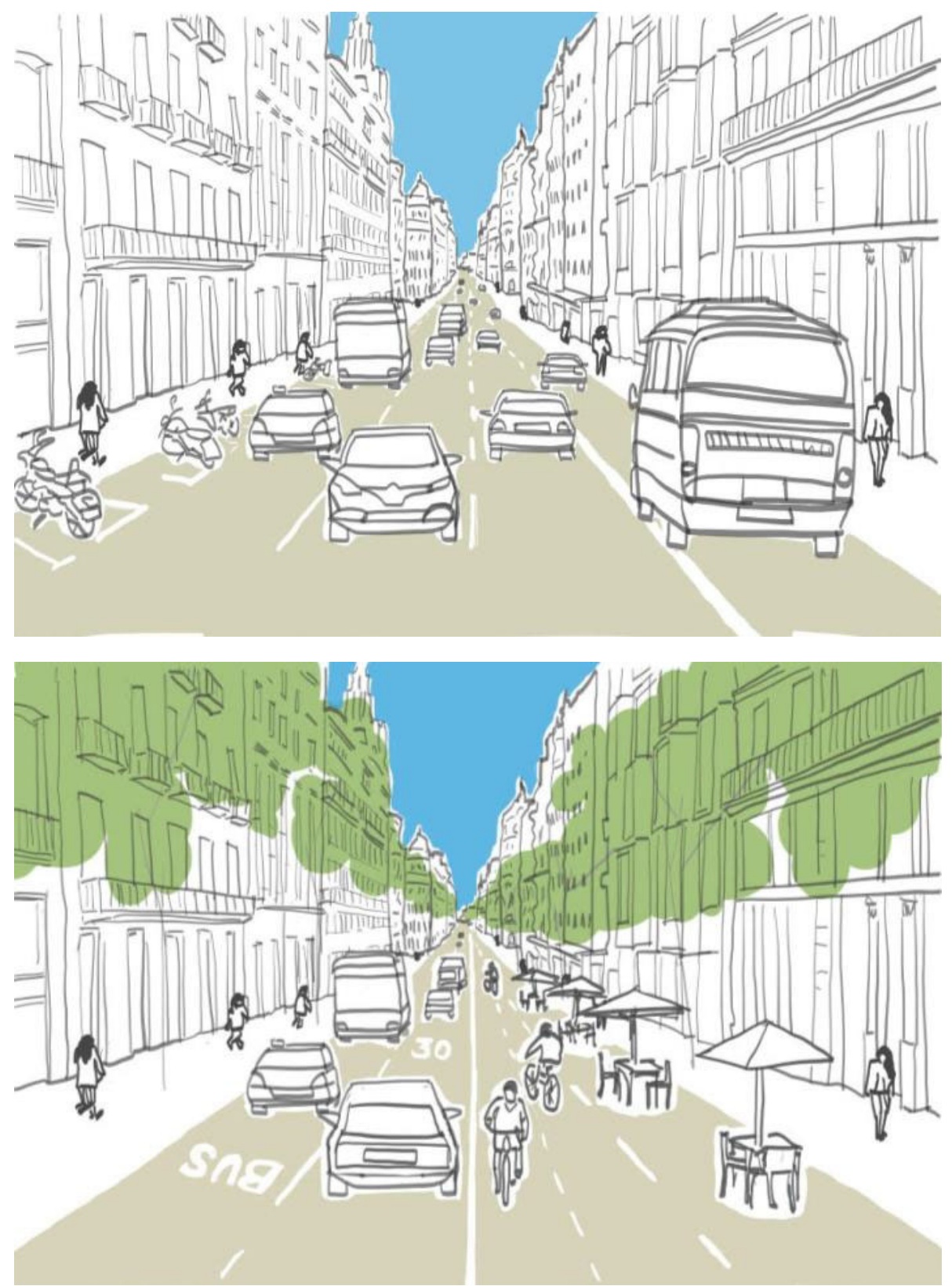

Figure 3. Imagine the redesign of streets in Barcelona. Source: by the authors 
A city like Barcelona (as many other European cities), it is deep into a process of reducing the presence of cars in the streets in favour of other uses (civic, green or sustainable mobility modes) under the model of superblocks and peaceful routes. Walking is already an important way of moving in the central city (about $35 \%$ of journeys) but less than $4 \%$ of citizens ride bikes for their everyday movements (eSMARTCITY, 2020). The possibility of shifting the reductions in the use of the public transportation towards cycling is an alternative considered in many metropolis [from the tempoRERvélo (Compagnon \& Corby, 2020) in Paris, where about $650 \mathrm{~km}$ of longdistance bike lanes are going to be implemented in two months, to Bogota, where bike lanes are doubling the network of Transmillenium BRT. In Barcelona, the adaptation to the effects of the pandemic appears as an opportunity to improve the infrastructure for cycling and substantially increase the use of bikes for mid-distance journeys (up to I5 $\mathrm{km}$ ). In that sense, some measures previously considered could be accelerated: the development of a network of safe bike lanes not only urban but also interurban; services of shared bicycles of several sorts adapted to the needs of different users; a bike parking system related to intermodal hubs (like traditional train or metro stations or new access points to shared vehicles located in former gas stations, parkings or car dealers); an integrated ticket system making easy to combine different transportation modes (seamless intermodality); the development of applications for planning, booking and paying mobility services including bikes (mobility as a service).

If cities maintain the aim of limiting and reducing the presence of cars, the debate about how to redesign the public space is highlighted. In circumstances of social distance to avoid contagion, we need wider sidewalks and larger bike lanes, but also more room for recreative uses (like bar terraces and children playgrounds, smaller and separated), without forgetting the urgent need to make our cities greener. The street space is limited and therefore extremely valuable (particularly in Mediterranean cities), but it can be better shared between these different uses (Pérez Mendoza, 2020). The actions of tactical urbanism (Martí Casanovas, 2020) implemented these weeks (rapid, low cost, reversible interventions like ground painting or using mobile urban furniture) constitute an interesting laboratory to explore and test permanent changes in the transformation of our streets in order to build more peaceful cities: cleaner and less polluted, human centred and easily inclusive, slower and enabling new urban experiences.

\section{Should be our cities less dense? Decompressed density, complexity and proximity.}

A second issue that the pandemic has underlined are crowded public spaces. The concentration of people in public places respond to different phenomena: mass tourism, collective events (like sport matches or concerts) or the simple fact that many cities are quite dense. While the big social events should wait for some kind of collective immunity to be fully restarted, tourism is a sector that can undergo significant long term changes. To launch alternatives to mass tourism could be an opportunity. Ecotourism, based on the experiences of nature and the values of rural territories, appears as a source of local development for some interior areas. At the same time, online work could also enhance the move of some citizen to the countryside (López Letón, 2020). Both dynamics would contribute to achieve more balanced urban development between 
big metropolis and a network of distributed medium cities supporting less populated regions.

But from the urban point of view, a key question is about density. In order to avoid infectious diseases, our cities should become less dense? Probably not. In the XIX century, urban features were clearly a cause for the appearance and spreading of infectious diseases. The combination of high density with a lack of sanitary conditions in the water supply and sewage infrastructures, poor habitability of the dwellings and lack of public spaces explained the link between city and infections. Such conditions don't exist anymore, at least in the European city of the XXI century. In this context, nowadays the main concerns of public health related to the urban environment are respiratory and heart illnesses due to air pollution and a sedentary life (Higueras \& Pozo Menéndez, 2020). Therefore, a mobility model based on the use of car contributes directly to an unhealthy urban environment. A shift towards sustainable mobility (clean, efficiently intermodal, favourable to active modes of transportation like walking and cycling) is key to promote urban health. And density appears as one of the conditions to enhance a sustainable mobility. In one century, density evolved from being associated to infections to be a factor of public health.

Besides, a reasonable mid-high density ( 25.000 inhabitants/sqkm) is a crucial factor for an overall sustainable city. It makes possible to provide many services (from public transportation to energy) in an efficient way (with fewer costs) (Kamiya, 2020). Density is also a necessary condition for having a rich intense neighbourhood life. The combination of density with complexity (related to the diversity of uses) makes possible neighbourhoods full of proximity services. In such areas, residents can find whatever they need in their everyday life reducing the need of mobility. It's the principle that what matters in a metropolis is a high accessibility to the services it offers with a minimum mobility. The concept of self-sufficient neighbourhoods or the city of 15 minutes walking turn around these same ideas. The efforts to increase the diversity of uses in urban areas (combining housing, commercial activities, other services, and also more and more economic activities from a clean industrial sector) are at the core of the agenda of many cities.

However, mid-high density standards require a good system of public green spaces to be balanced [a "decompressed density", as referred by Salvador Rueda (Rueda, 2018)]. A good system implies not only enough outdoor spaces, but also a diversity of typologies (intended for different recreation uses) and a right distribution on the whole city. During the pandemic, when the use of public space needs some social distance, we wonder how we could better manage or increase it. Temporary regulations are implemented: timeslots for being outdoors related to ages or activities, or changing the use of some places during some time (for instance, a street closed to traffic that becomes a playground for some hours or an expecting plot transformed into a temporary square). Time appears as a rising factor in the governance of the city. In turn, to increase public space in dense consolidated metropolis is not easy. The lockdown period has seen the recovery of rooftops life in Mediterranean cities. It's a way to be explored, as it can strengthen some current trends: the importance of small community places, acting as transitions between private dwellings and fully public spaces; the naturalization of cities, with the greening of façades and rooftops; the memory of rich cultural and historical roots, because in the past, the rooftops were much more lively. 


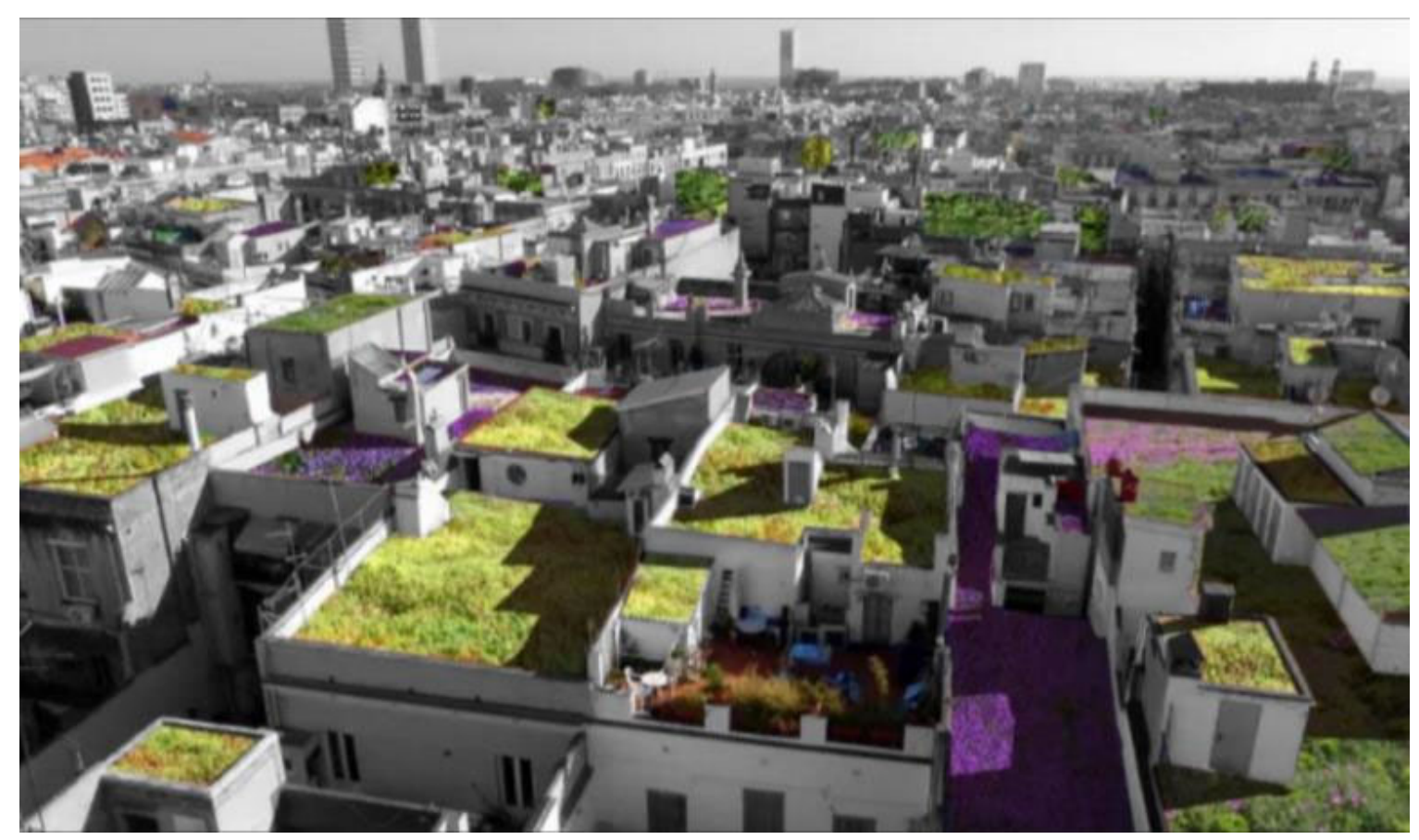

Figure 3. Proposal of green and community rooftops in the Raval neighbourhood of Barcelona Source: by the authors, based on an image of Barcelona Municipality. www.barcelona.cat/barcelonasostenible

Eventually, we could also change our habits and use more the big open metropolitan spaces [not only seafronts, but also mountains, rivers or agrarian parks that surround Barcelona (Batlle, 20I4)]. The dynamization of these rural spaces and their connection with the network of urban public places (through civic green corridors and permeable city edges enabling transition) is a main challenge for cities that could be enhanced by the impact of the pandemic.

\section{The increasing role of technologies: community initiatives and real time planning}

The last issue to be considered are the possible changes in the relation between public space and technology. The public sphere always shows two faces: the physical public space (streets, squares, parks) and the virtual public space (public opinion, social media, social networks). In the information and communication era, the online social space become progressively important (the last decades showing that this process doesn't undermine the vitality of the physical public space). The pandemic can accelerate this trend in several ways. On one hand, the rise of online interactions offers new opportunities and means to develop cooperative initiatives to build together [as Richard Sennet (Sennett, 2012) would put it] bottom up collective projects. On the other hand, our urban life will be more and more helped by technological applications. 


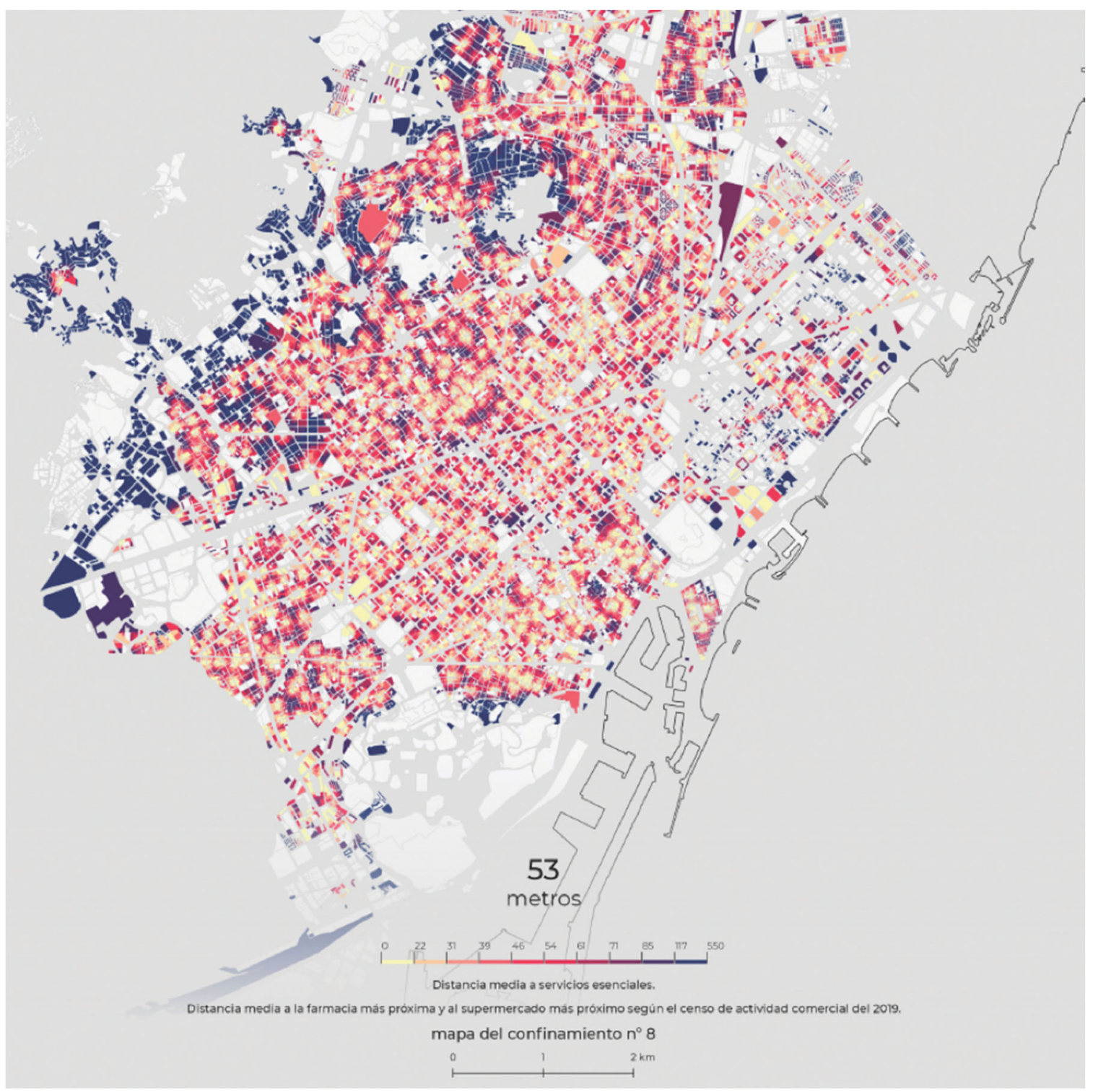

Figure 4. Neighbourhood proximity services in Barcelona: urban planning based on data analysis Source: http://www.300000kms.net/_arxiv/habitar.pdf

The analysis on real time of big amounts of data about how we move and use the city is increasingly present in urban governance. For instance, it will provide decision-making tools for more flexible urban planning and develop applications for intelligent traffic and public space management (synchronising traffic lights to adjust priorities between the flows of pedestrians, bikes and public transport or to control and limit the capacity of public space to avoid excessive crowds). To have access to these advantages of technologies implies that a lot of information on our personal life will be exposed, in the hands of public administrations or private corporations. A coercive use of this data by governments or a profit use by companies could involve a loss of freedom and privacy. But as Saskia Sassen (Sassen \& Sennet, 2020) states, such dangers should propel us to find efficient mechanisms to control the use of data, but never renounce to the great benefits of treating them properly. 
Sum up, in the field of urbanism and in relation with public space, the COVIDI9 pandemic is an opportunity to learn positive lessons in order to strengthen ongoing processes like the redesign of more green, calm, inclusive, healthy street spaces, the reconciliation with nature of our urban habits and lively neighbourhood environments and the use of new technologies for the construction and management of a city in which citizens can be fully engaged.

\section{References}

Batlle, E. (20/4). La matriu ecològica metropolitana i les diverses escales de les infraestructures verdes. Quaderns PDU Metropolità, Issue 3, pp. 6-25.

Compagnon, S. \& Corby, S. (2020). L'lle-de-France va investir 300 millions d'euros pour la réalisation du RER vélo. Le Parisien, 2104.

eSMARTCITY (2020). La ciudad de Barcelona transforma su movilidad urbana para adaptarse a la salida progresiva del confinamiento. Movilidad Urbana, 2904.

Guerrero, D. \& Muñoz, O. (2020). La desescalada amenaza con colapsar Barcelona. La Vanguardia, 0305.

Higueras, E. \& Pozo Menéndez, E. (2020). Urbanismo y salud: ¿Son las ciudades europeas resilientes a las pandemias?. The Conversation, 2304.

Kamiya, M. (2020). Densidad urbana, conceptos y políticas. El Comercio, 2404.

López Letón, S., 2020. El éxodo inmobiliario que viene tras el virus: de la ciudad al campo. El País, 0205.

Martí Casanovas, M. (2020). "Hay que ganar espacio para el uso de peatones y bicis durante la desescalada" [Interview] (28 04 2020).

Pérez Mendoza, S. (2020). José María Ezquiaga: "La ciudad pos-COVID será la ciudad posautomóvil". elDiario.es, 0605.

Rueda, S., 2018. Carta para la planificación ecosistémica de las ciudades y metrópolis, Barcelona: s.n. Sassen, S. \& Sennet, R. (2020). Desafios ante un futuro incierto [Interview] (20 04 2020).

Sennett, R., 2012. Together: The Rituals, Pleasures and Politics of Cooperation. New Haven, CT: Yale University Press.

Weisman, A. (2007). The World Without Us. New York: Thomas Dunne Books/St. Martin's Press.

Žižek, S., 2020. Pandemic!: COVID-I 9 Shakes the World. New York and London: OR Books. 